PSICOLOGIA, SAÚDE \& DOENÇAS, 2021, 22(1), 195-202

ISSN - 2182-8407

Sociedade Portuguesa de Psicologia da Saúde - SPPS - www.sp-ps.pt

DOI: http://dx.doi.org/10.15309/21psd220117

\title{
POSITIVE PSYCHOLOGY OF PORTUGUESE “DESENRASCANÇO” IN MULTIMORBIDITY: THE GENERAL PRACTITIONERS' PERSPECTIVE
}

\author{
Filipe Prazeres ${ }^{1,2,3}$, José Augusto Simões ${ }^{1,3,4}, \&$ Tim Lomas ${ }^{5}$ \\ ${ }^{1}$ Faculdade de Ciências da Saúde, Universidade da Beira Interior, Covilhã, Portugal, filipeprazeresmd@gmail.com \\ ${ }^{2}$ USF Beira Ria, Gafanha da Nazaré, Portugal \\ ${ }^{3}$ Centre for Health Technology and Services Research (CINTESIS), Porto, Portugal \\ ${ }^{4}$ USF Caminhos do Cértoma, Pampilhosa, Portugal, jars58@gmail.com \\ ${ }^{5}$ University of East London, School of Psychology, London, United Kingdom, t.lomas@uel.ac.uk
}

\begin{abstract}
The untranslatable word desenrascanço, a Portuguese construct related to people's ability to skilfully negotiate complex issues and to solve them with originality and creativity, was studied using a common medical complex scenario - multimorbidity. An online qualitative survey was carried out in the last trimester of 2018. A total of 117 general practitioners (GPs) completed the full survey. Ninety-one $(77.8 \%)$ were familiar with the concept of desenrascanço. Responses were coded using thematic analysis. Desenrascanço is commonly used by GPs; 77 out of 91 GPs use desenrascanço in at least half of the appointments with multimorbid patients. Three components of desenrascanço were identified: adaptive response; creativity and art; and positivity. It could conceivably be hypothesised that the positive drive of desenrascanço (e.g. creativity) are used by GPs collectively to adapt to multimorbidity - a medical complex situation. Nonetheless, one should not forget that it may not be the ideal solution, as stated by participant GPs.

Keywords: multimorbidity, primary care, desenrascanço, untranslatable word.
\end{abstract}

\section{PSICOLOGIA POSITIVA DO "DESENRASCANÇO" NA MULTIMORBILIDADE: A PERSPETIVA DOS MÉDICOS DE FAMÍLIA}

RESUMO: A palavra desenrascanço, sem tradução para inglês, construto português relacionado com a habilidade das pessoas em negociar, com habilidade, questões complexas, e de resolvê-las com originalidade e criatividade, foi estudado usando um cenário médico complexo e frequente: a multimorbilidade. Uma investigação qualitativa, online, foi realizada no último trimestre de 2018. Um total de 117 médicos de família (MF) completaram a pesquisa. Noventa e um $(77,8 \%)$ estavam familiarizados com o conceito de desenrascanço. As respostas foram codificadas por meio de análise temática. Desenrascanço é comummente usado por MF; 77 de 91 participantes usam desenrascanço em pelo menos metade das consultas com pacientes com multimorbilidade. Foram identificados três componentes do desenrascanço: resposta adaptativa; criatividade e arte; e positividade. Pode-se supor que o impulso positivo do desenrascanço (por exemplo, a criatividade) é usado pelos MF coletivamente para se adaptarem à multimorbilidade -

Faculdade de Ciências da Saúde, Universidade da Beira Interior, 6200-506 Covilhã, Portugal, email: filipeprazeresmd@gmail.com 
uma situação médica complexa. No entanto, não se deve esquecer que esta pode não ser a solução ideal, conforme afirmado pelos MF participantes.

Palavras-Chave: multimorbilidade, atenção primária, desenrascanço, palavra intraduzível.

Recebido em 17 de setembro de 2020/ Aceite em 28 de março de 2021

"David somehow MacGyvers a defibrillator from scraps around the house in order to resuscitate one of the characters who gets buried alive, and it works." (Oxford Dictionaries - English)

As an international field, psychology has been accused of being Western- and English-centric, with much of its theorising and discourse conducted in English. This means it is at risk of overlooking the insights into the mind developed within non-English speaking cultures, such as concepts that are not found in English (i.e., so-called "untranslatable" words). An important example of such a concept is desenrascanço, which has considerable relevance in terms of people's ability to skilfully negotiate complex issues and to solve them with originality and creativity. As an example, this may include the crossing of a river without knowing how to swim or a timely phone call that frees someone from the stalemate he/she was in (Academia das Ciências de Lisboa, 2001).

Desenrascanço is a Portuguese word previously considered to be a construct that the English language should adopt (Diário de Notícias, 2009; Observador, 2015). It can be explained as "the lastminute improvisation of a hasty but perfectly sound solution; pulling a MacGyver" (Observador, 2015). Improvisation "implies not wanting to be perfect. To stop control everything. Accept what we are, good and bad, and put it into action" (Briga, 2012).

Portuguese dictionary defines desenrascanço as the "ability to solve problems or difficulties quickly and without the adequate means" (Dicionário Priberam, 2020). Desenrascanço as a skill of improvisation is said to be part of the Portuguese character; people also known to be creative, innovative, skilled, hard-working, responsible (Castañeda, 2012), and with a positive anarchism unexpected and unpredictable (Daehnhardt, 2012).

Desenrascanço is considered to be a valued asset in some settings, especially the ones that require innovation since desenrascanço is linked to creativity (Público, 2006). But what about the medical setting? Is not medicine as much an art as it is a science? (Panda, 2006).

The authors hypothesize that Portuguese physicians use desenrascanço - imaginative resources combined with previous knowledge - when facing difficult situations during medical appointments. Mostly, when managing patients with multiple chronic diseases (i.e. multimorbidity), a current major challenge for general practitioners (GPs) (Watt, 2017).

In Portugal, as it is in many countries, the frequency of people with multimorbidity using Primary Health Care is very high (Prazeres \& Santiago, 2015; Violan et al., 2014). It is in this context that GPs and other health professionals work together to manage the complex needs of multimorbid patients. However, there are still no acceptable guidelines to manage complex multimorbid patients (Upshur, 2014).

Since the use of desenrascanço is positively considered as a tool to solve problems and because managing multimorbid patients is frequent and challenging for GPs, the current study i) asked GPs to define desenrascanço and ii) analysed the extent of the use of desenrascanço in the management of multimorbid patients. 


\section{METHODS}

\section{Participants}

A qualitative survey was carried out in the last trimester of 2018. A web-based questionnaire was employed since it was previously proven to be an uncomplicated, effective and fast data collection method; our team had used this approach before (Prazeres \& Santiago, 2016).

National GPs were eligible to be included in the study; excluding those who refused to participate and those who stated not to be familiar with the construct desenrascanço. Since there was an interest in collecting material about GPs' opinions and experiences and not point estimates for the population at large, no calculations were performed to estimate sample size. The studied GPs' sample was a convenience one aiming at maximizing variation regarding sex, age, academic degree, career level, experience in primary care, and practice type. Sampling ceased after saturation (e.g. until no further key themes were found) (Chapman et al., 2015).

In order to reach and recruit GPs, recruitment approaches using the Internet were chosen: the link to the web-based questionnaire was published on medical forums, online communities, and social media channels. Participation was voluntary, and no payment was offered to those who completed the survey.

The present study complies with the ethical principles of the Declaration of Helsinki (World Medical Association, 2013). The study protocol was assessed and approved by the Ethics Committee at University of Beira Interior no. CE-UBI-Pj-2018-049: ID717. The reporting of the current study conforms to the Standards for Reporting Qualitative Research (SRQR) guidelines (O'Brien et al., 2014).

\section{Material}

An electronic questionnaire was designed for data gathering. It included both closed-ended and open-ended questions. One section consisted of standard demographic questions. The other section consisted of 7 questions: Are you familiar with the concept of desenrascanço? (yes/no); In your opinion, what is the meaning of desenrascanço? (open-ended); How often do you use desenrascanço when dealing with multimorbid patients? (measured on a 5-point scale); What are the reasons for using desenrascanço when dealing with multimorbid patients? (open-ended); In what situations do you use desenrascanço when dealing with multimorbid patients? (open-ended); In your opinion, are current medical guidelines useful in dealing with multimorbid patients? (yes/no); Justify your answer (open-ended).

The final questionnaire was uploaded online after being pre-tested and reviewed for comprehensibility by a panel of experienced GPs. Its completion was anonymous. No incomplete questionnaires were collected.

\section{Data Analysis}

For content analysis a 4-step model (Chapman et al., 2015) was used: i) immersion in the raw data and organization into codes; ii) identification of themes or categories; iii) review themes and define structure among them; iv) construction of the theoretical model. The content analysis of the data started from the first received questionnaire at the same time still receiving the other questionnaires. Data analysis was undertaken in Portuguese. The data were studied using MAXQDA 2018. The final report of the findings was written in English. Descriptive statistics were used to analyse the quantitative information. 


\section{RESULTS}

A total of 117 GPs completed the full survey. Ninety-one (77.8\%) were familiar with the concept of desenrascanço and so the following results were based on their responses. There was a wide demographic variation of respondent GPs (Table 1).

Table 1. Physicians characteristics $(n=91)$

\begin{tabular}{|c|c|c|}
\hline Characteristic & $n(\%)$ & Mean $(S D)$ \\
\hline \multicolumn{3}{|l|}{ Sex } \\
\hline Women & $62(68.1)$ & \\
\hline Men & $29(31.9)$ & \\
\hline Age (years) & & $\begin{array}{c}39.57(12.38) \\
\min =26 ; \max =66\end{array}$ \\
\hline \multicolumn{3}{|l|}{ Academic degree } \\
\hline Entry-level medical degree (MD) & $65(71.4)$ & \\
\hline Higher medical degrees (Postgraduate/Master/PhD) & $26(28.6)$ & \\
\hline \multicolumn{3}{|l|}{ Career level } \\
\hline GP & $69(75.8)$ & \\
\hline GP in training & $22(24.2)$ & \\
\hline Experience in primary care (years) & & $\begin{array}{c}12.04(12.17) \\
\min =1 ; \max =42\end{array}$ \\
\hline \multicolumn{3}{|l|}{ Practice type } \\
\hline Family Health Unit (family practice-based model) & $62(68.1)$ & \\
\hline Personalized Healthcare Unit (individual based model) & $29(31.9)$ & \\
\hline \multicolumn{3}{|l|}{ Use of desenrascanço (\% of appointments) } \\
\hline Nil & $6(6.6)$ & \\
\hline $25 \%$ & $17(18.7)$ & \\
\hline $50 \%$ & $29(31.9)$ & \\
\hline $75 \%$ & $29(31.9)$ & \\
\hline All & $10(11.0)$ & \\
\hline
\end{tabular}

Portuguese desenrascanço defined by GPS

Adaptive response

GPs defined desenrascanço as an adaptive response to complex or chaotic situations where medical resources (e.g. human, capital, time) are low or absent. Desenrascanço is said to be used to solve problems and deal with difficulties.

Desenrascanço is the art of using minimal resources to face major challenges." (GP \#7)

Creativity and Art

Desenrascanço was considered by GPs to be the art of combining medical knowledge, past experiences, and improvisation to rapidly and effectively achieve the desired goals - to help the patient. It requires resilience, endurance, and creativity.

"Aptitude to find alternative means/techniques to provide the best health care in a context of limited services." (GP \#95)

Positivity

Participants considered desenrascanço as a positive construct, a GP that uses desenrascanço adopts an attitude of action. Usually, the solution that arises from desenrascanço is the less obvious 
and may not be the ideal one. And although it results from a non-structured plan, it was said to solve the patients' problems.

"Solve problems effectively in the shortest possible time and with the means available, even if not ideal." (GP \#45)

\section{Reasons for using desenrascanço when dealing with patients with multimorbidity}

Overcome constraints and barriers

Participants believe that when dealing with multimorbidity all medical appointments with GPs must end with a management plan. But since this cannot be currently achieved because of several constraints, GPs use desenrascanço to overcome these constraints (or barriers) and attain effective and holistic care.

"[The reason is] the lack of the most appropriate resource for the situation at hand." (GP \#77)

The current constraints pointed out by GPs were: i) short duration of each appointment slot; ii) unavailable or poorly designed health information technology; iii) lack of multidisciplinary professionals in the healthcare centres; and iv) barriers between GPs and secondary care providers (long waiting times or distance to reference hospital).

"Time allocated to each appointment slot; unavailable/poorly designed information systems; interface with other specialties and institutions not operational; aim and organization of work in Primary Health Care works against patients/priority to healthy individuals." (GP \#85)

GPs stated that desenrascanço is also used to overcome their own difficulties when dealing with multimorbid patients: i) management of medication; ii) management of family and community resources; iii) patients' lack of understanding their diseases and poor health literacy; and iv) dealing with difficult feelings.

Overcome guidelines insufficiencies

GPs considered that desenrascanço is "necessary to reconcile several guidelines and adapt the management plan to the patient's situation and context, and in a way that he accepts it" (GP \#49). GPs stated that there is no guideline or gold-standard that responds immediately to doubts raised when dealing with multimorbid patients.

Satisfy patient expectations

Desenrascanço is also used to satisfy patient expectations during consultations since GPs feel that sometimes "there is nothing else to offer to multimorbid patients" (GP \#112).

\section{Situations where desenrascanço is used to deal with patients with multimorbidity}

\section{$\underline{\text { Lack of resources }}$}

Some GPs stated that the practice of medicine is an art, not an exact science, and because of this all consultations would require a certain amount of desenrascanço. Nonetheless, situations where good working conditions or resources are lacking, are the ones where desenrascanço is most commonly used by GPs. It is an act dictated by the GPs' conscience to overcome the National Health Service (SNS) insufficiencies.

"When the appointment is already delayed [by overbooking] and I do not have enough time to consult another GP for the right course of action, or when I do not have enough time to search for the most correct information" (GP \#2)

"When the patient needs a hospital appointment, but it takes too long to book; when a patient does not have the necessary economic resources to buy medication; when the patient does not have the necessary family or social support to adhere to the therapeutic plan; when he needs an exam that the hospital takes months to conduct." (GP \#17) 


\section{Vagueness and ambiguity}

GPs use desenrascanço when having to manage nonspecific complaints or when they do not fit within the scope of the chronic diseases presented by the patient. Dealing with polypharmacy, with clinical guidelines incompatible with each other, and also when it is impossible for the patient to comply with the most appropriate advice, GPs also use desenrascanço.

\section{Are current medical guidelines useful in dealing with patients with multimorbidity?}

Most GPs $(n=56)$ consider that current medical guidelines are not useful to deal with multimorbidity. Most guidelines focus on a single disease and guide the GP's work by ignoring the variations that result from multimorbidity. There is no reference to which health conditions should be treated first or preferentially. And there are insufficient guidelines that consider multimorbid polymedicated patients.

\section{DISCUSSION}

The current study explored the definition of desenrascanço, a Portuguese construct associated with solving complex issues. Furthermore, multimorbidity was used as the perfect example of a common medical complex scenario to evaluate the extent of the use of desenrascanço by GPs.

Desenrascanço is commonly used by GPs; 77 out of 91 GPs use desenrascanço in at least half of the appointments with multimorbid patients. It has an unquestionable place in the medical scenario of multimorbidity.

Three components of desenrascanço were identified: adaptive response; creativity and art; and positivity.

Desenrascanço is not used by GPs to modify themselves in a way that they could adapt to their environment - Cohen's first definition of adaptation (Cohen, 2012). These results were expected since previous literature showed that GPs consider that the burden of managing multimorbidity is mostly caused by environmental factors (Sinnott et al., 2013). The most significant changes have to come from the environment and not the GP itself; GPs are known to have the tools to manage multimorbidity (Prazeres \& Santiago, 2016).

In an environment where resources are lacking, GPs adaptation results in a fast response that provides the greatest benefit for the patient. GPs successfully use experience-based creativity to solve their difficulties - Cohen's second definition of adaptation (Cohen, 2012). Cohen's third definition of adaptation, when the individual is capable of transforming its environment, was only briefly referred by participant GPs. It seems possible that these results are due to the GPs belief that the lack of resources is not dependent on them but rather caused by inadequacies of the health system, and therefore immutable to changes.

Some authors argue that medicine is both an art and a science, and that a good physician must be an artist with scientific knowledge (Panda, 2006); desenrascanço may be one of GPs artistic problemsolving tools when managing multimorbidity. Even with the current progress of medicine, vagueness and ambiguity still reside in the GP-multimord patient relationship and artistic qualities may have to be used - the human elements of GPs.

Hence, it could conceivably be hypothesised that the positive drive of desenrascanço (e.g. creativity) is used by GPs collectively to adapt to multimorbidity - a medical complex situation. Nonetheless, one should not forget that it may not be the ideal solution, as stated by participant GPs.

The generalisability of these results is subject to certain limitations. Although the open-ended questions format gave GPs the freedom to demonstrate their knowledge, the absence of a trained interviewer may have hindered the interpretation of some questions. Second, GPs who did not have access to the Internet were not recruited. Notwithstanding these limitations, the current study is the 
first to examine the psychological processes of problem-solving skills in a medical context through a concept not found in English.

Several questions remain unanswered at present. Is desenrascanço a personal preference of some GPs or a social norm? When dealing with multimorbidity, if at some point GPs working conditions or available resources improve would the use of desenrascanço diminish? And how effective is desenrascanço when dealing with multimorbid patients? These would be fruitful areas for further work.

Desenrascanço has a place in the medical scenario of multimorbidity. Adaptive response; creativity and art; and positivity are the components of desenrascanço. One should not forget that it may not be the ideal solution for the management of multimorbidity.

\section{REFERENCES}

Academia das Ciências de Lisboa. (2001). Dicionário da Língua Portuguesa Contemporânea. Academia das Ciências de Lisboa e Editorial Verbo.

Briga, V. (2012). De Clone a Clown. A arte de ter (e vender) Ideias Criativas. Vida Economica Editorial.

Castañeda, L. (2012). A Arte Converter Planos de Negócios em Resultados Rentáveis: Implementação. Vida Económica.

Chapman, A., Hadfield, M., \& Chapman, C. (2015). Qualitative research in healthcare: an introduction to grounded theory using thematic analysis. The Journal of the Royal College of Physicians of Edinburgh, 45(3), 201-205. https://doi.org/10.4997/JRCPE.2015.305

Cohen, L. M. (2012). Adaptation and creativity in cultural context. Revista de Psicología (Lima), 30(1), $\quad$ 03-18. $\quad \mathrm{http}: / /$ pepsic.bvsalud.org/scielo.php?script=sci_arttext\&pid=S025492472012000100001

Daehnhardt, R. (2012). Identidade Portuguesa - Por que a Defendo. Apeiron Edições.

Diário de Notícias. (2009). "Desenrascanço" faz falta no léxico inglês. https://www.dn.pt/tv-emedia/media/desenrascanco-faz-falta-no-lexico-ingles-1206424.html

Dicionário Priberam. (2020). Desenrascanço. https://dicionario.priberam.org/desenrascanço

O’Brien, B. C., Harris, I. B., Beckman, T. J., Reed, D. A., \& Cook, D. A. (2014). Standards for Reporting Qualitative Research: a synthesis of recommendations. Academic Medicine, 89(9), 1245-1251. https://doi.org/10.1097/ACM.0000000000000388

Observador. (2015). A palavra em português que a língua inglesa inveja: "desenrascanço". https://observador.pt/2015/03/18/a-palavra-em-portugues-que-a-lingua-inglesa-invejadesenrascanco/

Panda, S. (2006). Medicine: Science or Art? Mens Sana Monographs, 4(1), 127-138. https://doi.org/10.4103/0973-1229.27610

Prazeres, F., \& Santiago, L. (2015). Prevalence of multimorbidity in the adult population attending primary care in Portugal: a cross-sectional study. BMJ Open, 5, e009287. https://doi.org/10.1136/bmjopen-2015

Prazeres, F., \& Santiago, L. (2016). The knowledge, awareness, and practices of portuguese general practitioners regarding multimorbidity and its management: Qualitative perspectives from openended questions. International Journal of Environmental Research and Public Health, 13(11). https://doi.org/10.3390/ijerph13111097

Público. (2006). Cultura do desenrascanço pode ser mais-valia nacional. https://www.publico.pt/2006/11/22/jornal/cultura-do-desenrascanco-pode-ser-maisvalianacional-108612 
Sinnott, C., Mc Hugh, S., Browne, J., \& Bradley, C. (2013). GPs' perspectives on the management of patients with multimorbidity: systematic review and synthesis of qualitative research. $B M J$ Open, 3(9), e003610. https://doi.org/10.1136/bmjopen-2013-003610

Upshur, R. E. G. (2014). Do Clinical Guidelines Still Make Sense? No. The Annals of Family Medicine, 12(3), 202-203. https://doi.org/10.1370/afm.1654

Violan, C., Foguet-Boreu, Q., Flores-Mateo, G., Salisbury, C., Blom, J., Freitag, M., Glynn, L., Muth, C., \& Valderas, J. M. (2014). Prevalence, Determinants and Patterns of Multimorbidity in Primary Care: A Systematic Review of Observational Studies. PLoS ONE, 9(7), e102149. https://doi.org/10.1371/journal.pone.0102149

Watt, G. (2017). The subversive challenges of multimorbidity. British Journal of General Practice, 67(659), 280-281. https://doi.org/10.3399/bjgp17X691289

World Medical Association. (2013). World Medical Association Declaration of Helsinki: ethical principles for medical research involving human subjects. JAMA, 310(20), 2191- 2194. https://doi.org/10.1001/jama.2013.281053 